Article

\title{
Small-Scale Public Rental Housing Development Using Modular Construction-Lessons learned from Case Studies in Seoul, Korea
}

\author{
Jeong-hoon Lee ${ }^{1, *}$, Jin-sung Kim ${ }^{1}$, Hak-ju Lee ${ }^{2}$, Young-Min Lee ${ }^{1}$ and Hyung-Geun Kim ${ }^{1}$ \\ 1 Department of Seoul Housing and Communities Corporation, Urban Research Institute, Seoul 06336, Korea; \\ jskim77@i-sh.co.kr (J.K.); e0min@i-sh.co.kr (Y.L.); hgkim@i-sh.co.kr (H.K.) \\ 2 School of Civil, Environmental and Architectural Engineering, Korea University, Seoul 02841, Korea; \\ dlgkwngo@naver.com \\ * Correspondence: di5555@naver.com; Tel.: +82-10-8896-5956
}

Received: 1 February 2019; Accepted: 18 February 2019; Published: 20 February 2019

\begin{abstract}
Modular construction, which involves factory-based modular unit manufacturing followed by installation at a construction site, has been recognized as one of the sustainable construction methods. Its advantages are known to be implemented through (1) standardized design, (2) standardized production method, and (3) large-scale development (mass production system). These three conditions are basic requirements for modular construction market expansion, but it is difficult to define that these conditions are a prerequisite for judging whether modular construction applied or not. Nevertheless, public development companies in regions or countries where modular construction has just begun thought that modular construction should meet all three conditions that are suitable for applying public construction projects. This is because it is difficult to compare conventional construction projects with similar conditions to modular construction projects. This paper analyzes the cost and duration data of three small-scale public construction rental housing (PCRH) projects involving modular construction in Korea. These cases presented herein include a public college student dormitory, public low-rise rental housing, and public mid-rise rental housing in small-scale development projects. Those were applied not standardized design (common design and regulation), but were reflected in each project's demands (different design and regulation). To compare it, this paper analyzed 91 public housing provision projects' construction data from 2011 to 2017 from one of the public rental housing provision companies in Korea. Among them, 19 small-scale public rental housing data were extracted for comparing with modular construction project data. The results show that, even if not standardized, the design and production process, and modular construction durations, were more effective-but costs were similar or expensive. Based on the conclusion drawn from three cases, this paper presents important considerations for the application of modular construction in other small-scale public construction rental housing projects from the perspective of public development companies.
\end{abstract}

Keywords: case studies; small-scale housing development; sustainable development; modular building construction; public construction rental housing; construction costs and durations; Korea

\section{Introduction}

Following Butlin and Bruntland defines sustainable construction as "development that meets the needs of present without compromising the ability of future generations to meet their own needs" [1,2]. Current sustainable construction goals are focusing on improved efficiency [3], waste minimization and pollution prevention [4]. WBDG (Whole Building Design Guide) defines "the main objectives of sustainable design are to reduce, or completely avoid, depletion of critical resources like 
energy, water, land, and raw materials; prevent environmental degradation caused by facilities and infrastructure throughout their life cycle; and create built environments that are livable, comfortable, safe, and productive [5]." Considering both sustainable construction and sustainable design definitions, current construction industry faces the challenge of finding new ways to replace existing construction methods at the beginning of the design stage.

Modular construction is combined with the manufacturing process (working environment) and conventional construction works (working regulation) [6,7]. It is used worldwide as a result of the high quality, low construction costs, and short construction times involved [8-10]. It refers to one of the sustainable construction methods. Fred et al. investigated that performance of modular prefab construction based on case study. This paper introduced several modular construction cases and organized five performance investigation categories; thermal behaviour, acoustic constraints, seismic resistance, energy consumption, and lift cycle analysis. One of the research results shows that mass customization is one of the important factors to the commercialization of modular construction [11]. Shen et al., used questionnaire and field investigation methods for comparing the effects of costs, and benefits prefabrication housing with conventional housing [12]. The results show that prefabricated housing has more environmental benefits than conventional construction methods in energy consumption.

It was introduced in 2003 and has been applied in numerous projects in Korea, such as military offices, retail stores, temporary residential facilities, and residential houses [13]. Although there are many modular construction cases, there is little analysis as to whether it has actually more applicable to small-scale public construction projects than conventional construction methods in Korea. Because public development owners believed that some of the conditions (standardized design and production process, large-development projects) would have to be met at the same time. This paper analyzed three public rental housing systems and three completed modular building construction projects (a public dormitory, low-rise public rental housing and mid-rise public rental housing) in Korea for analyzing the advantages and disadvantages of applying modular construction in public construction rental housing (PCRH) projects. To do this, this study used information from 2011 to 2017 on the public delivering public construction rental housing project construction data to define a current small-scale public rental housing problem. Then, the results from substituted modular projects and projects using modular construction methods were compared with those from projects using conventional construction with standard construction duration and cost calculations. After that, this paper proposes additional requirements for public housing provisions that use modular construction.

\section{Literature Review}

\subsection{Sustainable Development through Modular Construction}

The small-scale public rental housing in urban areas is as difficult as for large-scale development projects. This is because the level of environmental regulation to be followed during the construction project is low, but the contents are all the same. It takes too much cost to meet these conditions which leads to poor business efficiency. In contrast, off-site construction (including prefab construction and modular construction) has been known as possible to reduce construction duration and costs, increase quality, and reduce construction wastes through the manufacturing process [14-17]. One of the reasons for the advantages of modular construction is using standardization design and process. Xie et al., defines "Standardization is the process of developing and implementing specifications based on the consensus of the views of firms, users, interest groups and governments" [18]. This paper found that standardization has both benefits and challenges concurrently. Also, it suggests that long-term planning is needed to reflect demand from both users and suppliers. Following Cheng, the Hong Kong Authority developed "a new library of Modular Flat Design (2008 version)" for implementing at the scheme design stage in public rental housing. Its main purposes are reducing (1) construction costs ( $34 \%$ less costly), (2) construction waste (generating 30\% less), and (3) accident rates (75\% less accident 
rates), than conventional construction for sustainable development [19]. This paper emphasized that design and production standardization needed, but it requires the assessment of architectural, structural, and building services. Aapaoja emphasized that standardized processes and products are key elements for achieving the advantage of prefabrication [20]. To do this, Gibb argued that numerous researches and case studies are needed to decide standardizations of design and production considering regional requirements [21]. Nevertheless, modular construction has still barriers to enhance the construction market. Jiang et al. investigate major factors relating barriers of prefabricated construction development in China using a questionnaire survey. The results show that one of the reasons is a lack of integrated design [22]. The standardization of modular design requires not only structural materials but also unit size and installation methods [8]. The final results of these efforts are expected to satisfy all of the modular manufacture, client requirements, and economics. In Malaysian, Sustainable Modular Industrialized Building System (IBS) has been adopted from 2006 [23]. Its main goals are (1) reducing the dependency on foreign labor, and (2) saving the country's loss in foreign exchange [8,24]. The Modular IBS also provides improved solutions relating reduce the environmental effect based on sustainable construction design. Despite those advantages, a sustainable design concept for modular construction is difficult for designers and architects, because of lack of understanding of modular process [25]. Pan et al., investigated the views of UK housebuilders on the modular construction, using an extensive questionnaire survey of top 100 housebuilders [26]. The research results show that complex interfaces and design challenges (difficult to satisfy the standard design concept considering manufacturing and site installation environment) still exist in modular construction. In other words, design standardization can be both an advantage and a disadvantage of modular construction.

\subsection{Characteristics of Public Rental Housing in Korea}

As of 2010, single-person households accounted for 23.9\% of the total households in South Korea. Between 2000 and 2010, the number of single-person households in Seoul, where the capital city of South Korea, was increased 1.7 times from 502,000 households to 855,000 households, due to individualism, an increase the number of single-elder households, due to aging, and an increase in divorce rates. Statistics Korea (2018) data indicate that one or two-people households were 3,640,000 $(44.0 \%)$ in 2010 in Korea. It is also expected that it will be 5,150,000 households (53.8\%) in 2020 and 6,400,000 households (60.5\%) in 2030 [27]. Due to large-scale development in the city centre involving reconstruction and redevelopment, however, small-single and multi-family houses have been destroyed. In the last two decades, the number of small-scale houses ( $32 \mathrm{~m}^{2}$ or less) has decreased from 573,000 households (10.8\%) in 1980 to 252,000 households $(2.0 \%)$ in 2005 year.

In order to provide such housing, the Korean government has been promoting small-size and small-scale Public Rental Housing provision policies in the last few decades. It remains difficult to solve current problems stemming from rapidly increasing demand for small-scale public rental housing using current construction methods, such as site-based construction, which are limited by extended construction times, due to wet construction methods, and increased construction costs, due to project risks, such as lack of worker and weather conditions [28-30].

The Public Rental Housing (PRH) is defined in Korea according to Article 2, Paragraph 1 of the Housing Act, which is provided for the purposes of conversion after a lease or sale; there are seven main types of rental housing, as shown in Table 1. 
Table 1. Public rental housing definitions and contents in Korea.

\begin{tabular}{|c|c|}
\hline Category & Content \\
\hline Permanent rental housing & $\begin{array}{l}\text { Public rental housing financed by the state or } \\
\text { municipal governments and supplied for the purpose } \\
\text { of permanent residence of more than } 50 \text { years in } \\
\text { order to stabilize housing for lower income classes }\end{array}$ \\
\hline National Rental Housing & $\begin{array}{l}\text { Public rental housing funded by the national or local } \\
\text { government and funded by the Housing City Fund to } \\
\text { provide long-term rental for more than } 30 \text { years }\end{array}$ \\
\hline Happy Housing & $\begin{array}{l}\text { Public rental housing funded by the government or } \\
\text { local government and the Housing and Urban Fund } \\
\text { to provide housing for young people, such as college } \\
\text { students, seniors, and newlyweds }\end{array}$ \\
\hline Long-term chartered housing & $\begin{array}{l}\text { Publicly leased housing that is financed by the state } \\
\text { or municipal governments and the Housing Cities } \\
\text { Fund }\end{array}$ \\
\hline Renting an existing home & $\begin{array}{c}\text { Renting a home by purchasing an existing home with } \\
\text { funds from the state or local government, financed by } \\
\text { the local government or the Housing Cities Fund and } \\
\text { supplied to recipients under the National Basic } \\
\text { Livelihood Security Act }\end{array}$ \\
\hline Existing housing Leased rental houses & $\begin{array}{l}\text { Existing public leased housing financed by the } \\
\text { national or local governments or the Housing Cities } \\
\text { Fund and leased to low-income people }\end{array}$ \\
\hline Public rental housing converted into a pre-sale house & $\begin{array}{l}\text { Supplied for the purpose of conversion after a lease } \\
\text { of a given period }\end{array}$ \\
\hline
\end{tabular}

In Korea, PRH activities can be classified into two main categories: Public construction rental housing (PCRH) and public purchase rental housing (PPRH). PCRH includes buildings constructed and supplied by public housing companies. PPRH, on the other hand, involves purchasing previously constructed houses and supplying them to people in need of reasonable rental fees.

From a construction cost point of view, PCRH policies require new public land for construction and involve construction costs. PCRH is advantageous in that it involves site selection, design, and construction tailored for the tenants, providing tenants with housing facilities that meet their needs. On the other hand, PCRH requires significant time for the screening process, which includes deciding whether to go forward with construction, as construction expenses are paid with taxes. Therefore, PCRH requires high manpower, cost, and time requirements during the project feasibility assessment. On the other hand, PPRH involves the purchase and supply of previously constructed houses. Compared with PCRH, PPRH has advantages including reduced risk of increases in construction costs and shorter periods required for project feasibility assessment. When using PPRH methods, however, it is difficult to assess the quality of the pre-existing building and to accommodate the residential requirements of the tenants. It is difficult to adapt an appropriate rental price because these buildings, which are often located in urban areas, are too expensive to be provided for reasonable rental prices to people who need public rental housing. Considering the advantages and disadvantages of these two methods, PCRH methods have been more widely emphasized in public rental housing provision policy. PCRH, however, requires more project assessment time than PPRH and private construction projects (Table 2). 
Table 2. Summary of public construction rental housing (PCRH) and and public purchase rental housing (PPRH).

\begin{tabular}{lll}
\hline & $\begin{array}{l}\text { PCRH } \\
\text { (Public Construction Rental Housing) }\end{array}$ & $\begin{array}{l}\text { PPRH } \\
\text { (Public Purchase Rental Housing) }\end{array}$ \\
\hline \multirow{3}{*}{ Advantages } & $\begin{array}{l}\text { (1) Possible to ensure quality } \\
\text { (2) Possibilities for complex development } \\
\text { (e.g., public parking lots with residential building) } \\
\text { (3) Possible to apply latest technology }\end{array}$ & $\begin{array}{l}\text { (1) Possible to reduce overall costs } \\
\text { (2) No need to find a construction site } \\
\text { (3) Can be supplied faster than PCRH }\end{array}$ \\
\hline \multirow{2}{*}{ Limitations } & $\begin{array}{l}\text { (1) Longer construction duration than PPRH } \\
\text { (2) Costs more than PPRH }\end{array}$ & $\begin{array}{l}\text { (1) Difficult to ensure housing quality } \\
\text { (2) Difficult to supply various specific } \\
\text { housing types for tenants }\end{array}$ \\
\hline
\end{tabular}

\section{Current States of Public Rental Housing in Korea}

\subsection{Moving from Large-scale Development to Small-scale Development}

In the 1990s, public rental housing provisions were focused on quantitative supply in order to address housing problems, due to the growing urban population in Korea. Based on this provision policy, public rental systems and policy were aimed toward large-scale development projects. Since the 2000s, rapid urban development has slowed and awareness of tenants' rights has begun to increase. Moreover, new development methods are required to minimize the environmental destruction of the development target site. As a result, public rental housing provisions are gradually increasing their focus on the quality of life and improving housing welfare. In addition, owing to slowing economic growth, all age groups are increasingly demanding smaller homes (exclusive residential area under $85 \mathrm{~m}^{2}$ ) as their ability to purchase homes declines (Figure 1).

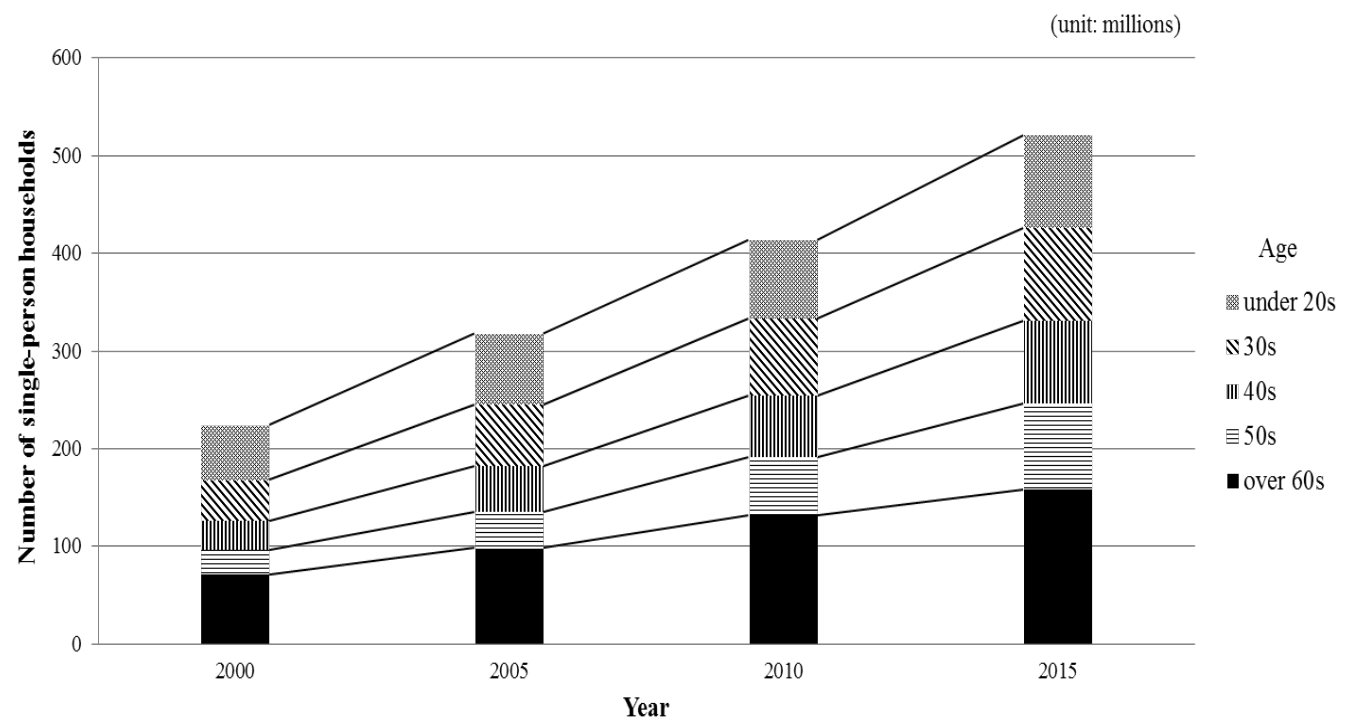

Figure 1. Number of single-person households in Korea (data from Statistics Korea, 2000-2015).

In other words, public rental housing provision methods should satisfy the residential requirements of both vulnerable groups and middle-class residents. This requires changing the housing supply system to differentiate rental fees and periods according to the housing size and housing type (Figure 2).

To accomplish this, it is necessary to develop small-scale residential complexes rather than conventional apartment-based large-scale residential developments. Considering these conditions, the PPRH method has limited ability to provide various specific housing types, such as public rental housing for single mothers, multigenerational families, and elderly couples. Thus, the PCRH method is more suitable (than the PPRH method) for providing public rental housing. PCRH using conventional 
construction methods, however, is not optimal for people in urgent need of public rental housing because construction takes longer and rent is more expensive than under PPRH.

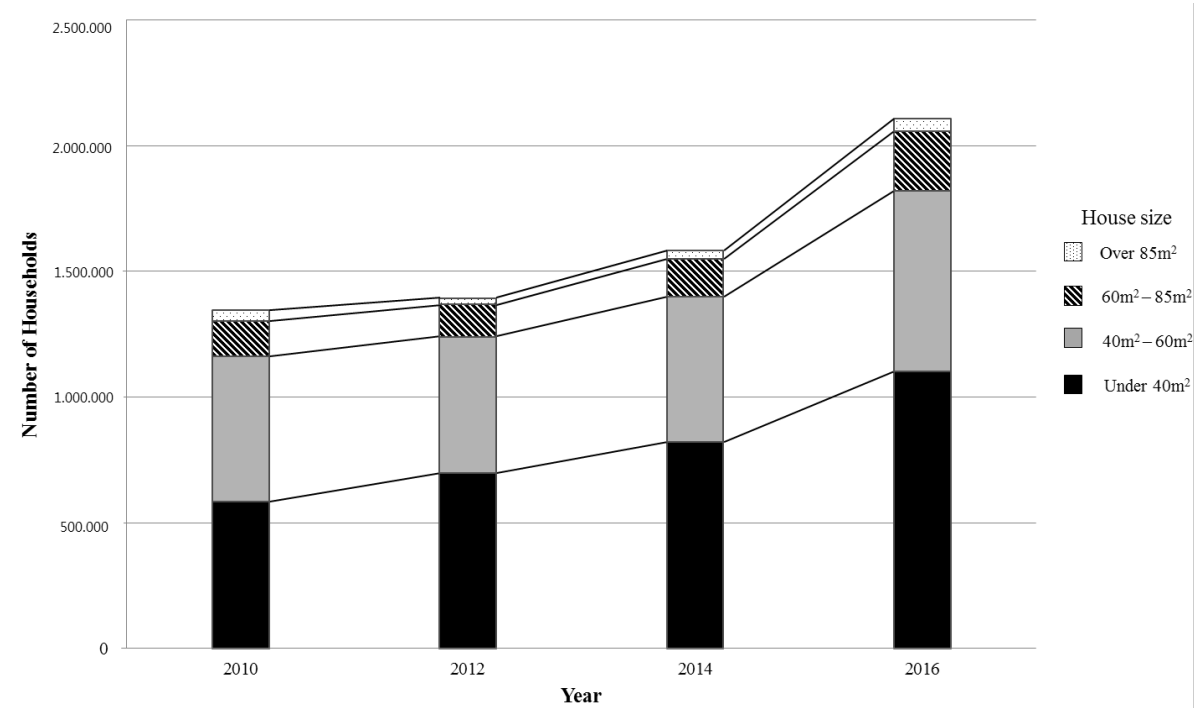

Figure 2. Increasing demand for small-sized public rental housing in Korea (data from Statistics Korea, 2010-2016).

\subsection{Small-scale PCRH Provision Problems in Seoul, Korea}

This study employed historical construction cost and duration data for the years 2011 to 2017 from the Seoul Housing and Communities Corporation, a public housing development organization in Korea, to analyse current public rental housing provision problems (Table 3).

Table 3. Number of households in various construction project groups.

\begin{tabular}{|c|c|c|c|c|c|c|c|c|}
\hline \multirow[b]{2}{*}{ Classification } & \multirow[b]{2}{*}{$\begin{array}{c}\text { Total } \\
\text { Households }\end{array}$} & \multicolumn{5}{|c|}{ Rental Housing } & \multicolumn{2}{|c|}{ Sales } \\
\hline & & $\begin{array}{c}\text { Permanent } \\
\text { Rental } \\
\text { Housing }\end{array}$ & $\begin{array}{c}\text { National } \\
\text { Rental } \\
\text { Housing }\end{array}$ & $\begin{array}{l}\text { Happy } \\
\text { House }\end{array}$ & $\begin{array}{c}\text { Long-term } \\
\text { chartered } \\
\text { housing } \\
\text { (Under } 85 \mathrm{~m}^{2} \text { ) }\end{array}$ & $\begin{array}{c}\text { Long-term } \\
\text { Chartered } \\
\text { Housing } \\
\left.\text { (Over } 85 \mathrm{~m}^{2}\right)\end{array}$ & $\begin{array}{l}\text { Sales } \\
\text { (Under } \\
85 \mathrm{~m}^{2} \text { ) }\end{array}$ & $\begin{array}{l}\text { Sales (Over } \\
\qquad 85 \mathrm{~m}^{2} \text { ) }\end{array}$ \\
\hline $\begin{array}{c}\text { Group A } \\
\text { (10 projects) }\end{array}$ & 365 & 0 & 166 & 128 & 71 & 0 & 0 & 0 \\
\hline $\begin{array}{c}\text { Group B } \\
\text { (9 projects) }\end{array}$ & 743 & 0 & 393 & 137 & 213 & 0 & 0 & 0 \\
\hline $\begin{array}{c}\text { Group C } \\
\text { (13 projects) }\end{array}$ & 2,458 & 0 & 892 & 467 & 595 & 46 & 295 & 163 \\
\hline $\begin{array}{c}\text { Group D } \\
\text { (12 projects) }\end{array}$ & 4,277 & 0 & 1,059 & 720 & 1,506 & 48 & 807 & 137 \\
\hline $\begin{array}{c}\text { Group E } \\
\text { (12 projects) }\end{array}$ & 5,273 & 0 & 1,157 & 0 & 1,659 & 159 & 1,823 & 475 \\
\hline $\begin{array}{c}\text { up F } \\
\text { (17 projects) }\end{array}$ & 10,446 & 146 & 2,652 & 0 & 3,386 & 617 & 3,093 & 552 \\
\hline $\begin{array}{c}\text { Group G } \\
\text { (16 projects) }\end{array}$ & 19,776 & 156 & 6,633 & 0 & 5,997 & 544 & 4,198 & 2,248 \\
\hline $\begin{array}{c}\text { Sum } \\
\text { (91 projects) }\end{array}$ & 43,338 & 302 & 12,952 & 1,452 & 13,427 & 1,414 & 10,216 & 3,575 \\
\hline
\end{tabular}

As of December 2017, a total of 91 public housing construction projects had been completed. It can be classified into seven categories: Projects with under 50 households (Group A), projects with 50 to 100 households (Group B), projects with 100 to 300 households (Group C), projects with 300 to 400 households (Group D), projects with 400 to 500 households (Group E), projects with 500 to 1,000 households (Group F), and projects with over 1,000 households (Group G). This result excludes construction data pertaining to electrical works, as all electrical works performed during public construction projects in Korea must be performed separately, involving different management areas 
and delivery method. Thus, it is difficult to analyse the construction data on the same basis. Using historical data for Groups A to G, overall average construction costs and durations are, as shown in Table 4.

Table 4. Average construction cost and duration from historical data.

\begin{tabular}{ccccccccc}
\hline \multicolumn{2}{c}{ Classification } & Group A & Group B & Group C & Group D & Group E & Group F & Group G \\
\hline \multirow{2}{*}{$\begin{array}{c}\text { Cost } \\
\text { (billion won) }\end{array}$} & Average & 19.4 & 60.5 & 203.4 & 360.6 & 550.4 & 895.4 & 1459.2 \\
\cline { 2 - 9 } & St. Dev. & 10.0 & 25.0 & 94.7 & 84.4 & 109.8 & 153.92 & 305.2 \\
\hline \multirow{2}{*}{$\begin{array}{c}\text { Duration } \\
\text { (days) }\end{array}$} & Average & 300.1 & 763.2 & 754.5 & 832.6 & 872.8 & 895.4 & 920 \\
\cline { 2 - 9 } & St. Dev. & 137.4 & 310.6 & 229.0 & 161.4 & 64.6 & 103.0 & 95 \\
\hline
\end{tabular}

As shown in Figures 3 and 4, small-scale public housing construction project groups (Groups A to C) have a higher increase rate of construction cost and duration than other groups (Groups D to G), which indicates that small-scale projects are more expensive and more difficult to manage (in terms of construction duration) than large-scale public rental housing construction projects. In particular, the rate of increase in the construction duration of Groups A and B was nearly two times higher than other construction projects. Taking into account the current challenging state of small-scale PCRH construction projects, these results show that conventional construction methods cannot satisfy providers and demanders in terms of both appropriate residential construction costs and duration.

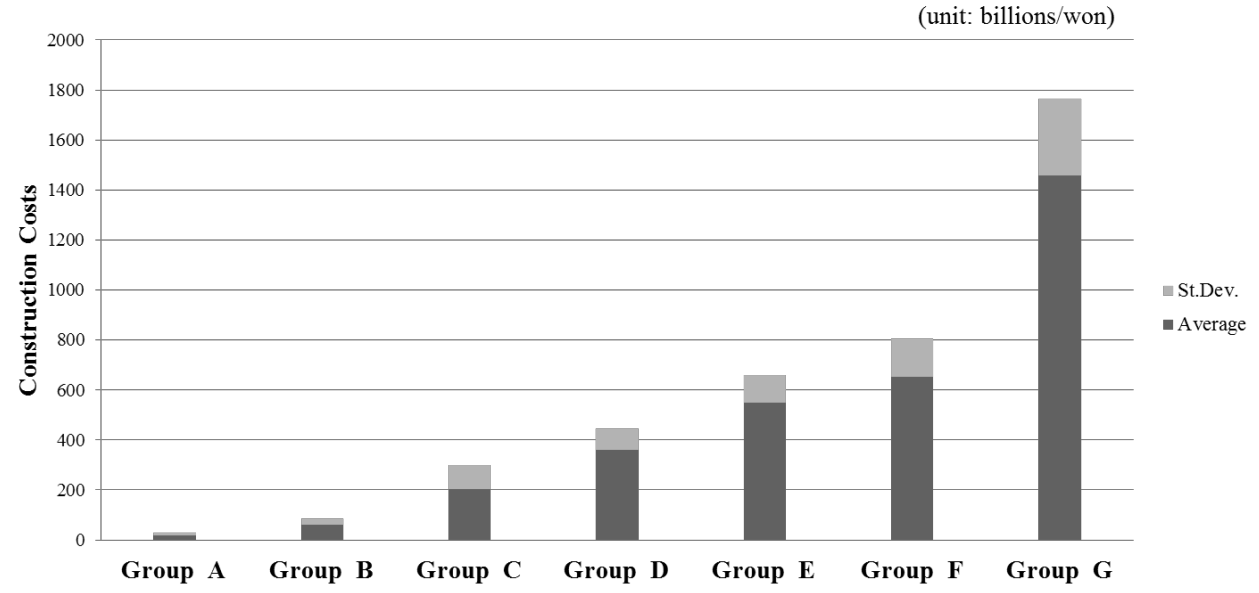

Figure 3. Comparison of average construction costs for each project group based on historical data from 2011 to 2017.

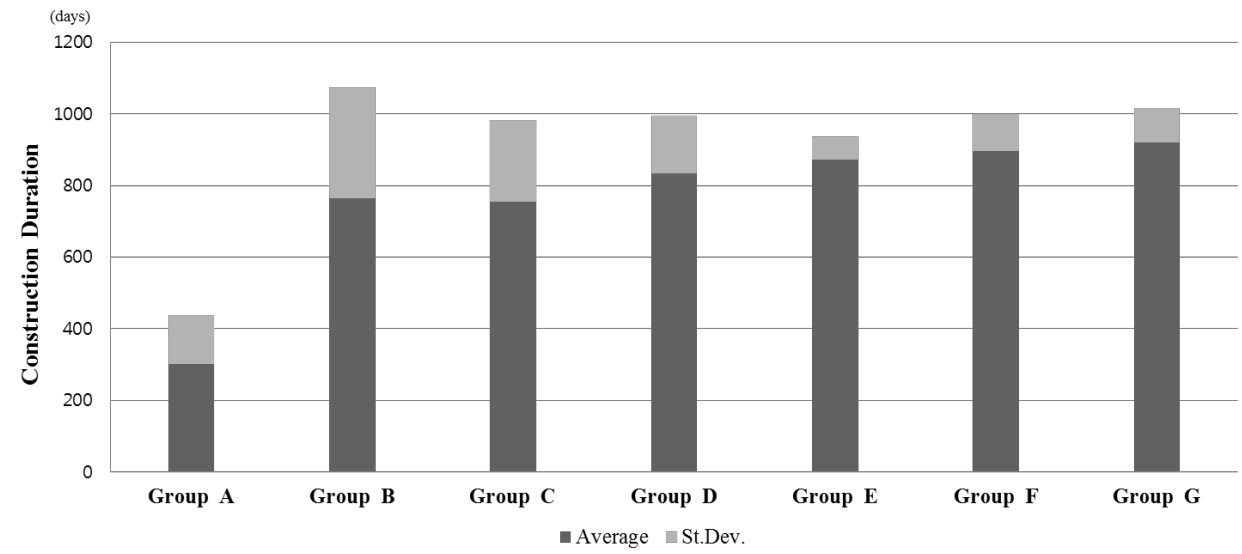

Figure 4. Comparison of average construction duration for each project group based on historical data from 2011 to 2017. 


\section{Case Studies}

In providing public rental housing, the public rental housing provision company decided to apply modular construction in the three different projects, shown in Table 5: Public dormitory (Project N) and two public rental housing projects (Projects S and G).

Table 5. Summary of three modular construction projects.

\begin{tabular}{|c|c|c|c|}
\hline & \multicolumn{3}{|c|}{ Project Classification } \\
\hline & Project N & Project S & Project G \\
\hline Project Title & $\begin{array}{l}\text { Public dormitory for } \\
\text { undergraduate students }\end{array}$ & $\begin{array}{l}\text { Public rental housing for } \\
\text { theater employees }\end{array}$ & $\begin{array}{c}\text { Modular Building } \\
\text { Construction of Happy } \\
\text { Public Rental Housing }\end{array}$ \\
\hline Target tenants & Undergraduate students & Theater employees & $\begin{array}{l}\text { Young people taking } \\
\text { their first steps } \\
\text { into society }\end{array}$ \\
\hline Construction Area & $258.24 \mathrm{~m}^{2}$ & $143.12 \mathrm{~m}^{2}$ & $371.65 \mathrm{~m}^{2}$ \\
\hline Location & $\begin{array}{l}\text { Gongneung-dong, } \\
\text { Seoul, Korea }\end{array}$ & $\begin{array}{l}\text { Seongbuk-gu, } \\
\text { Seoul, Korea }\end{array}$ & $\begin{array}{l}\text { Gayang-dong, } \\
\text { Seoul, Korea }\end{array}$ \\
\hline $\begin{array}{l}\text { Building Use Types } \\
\text { (PCRH type) }\end{array}$ & Dormitory & Public Rental Housing & Public Rental Housing \\
\hline \multirow[t]{2}{*}{ Main Structure } & $\begin{array}{l}\text { Modular Construction } \\
\text { - Foundation (Reinforced } \\
\text { concrete) + Steel frame } \\
\text { structure (Modular units) }\end{array}$ & $\begin{array}{l}\text { Modular Construction } \\
\text { - Foundation (Reinforced } \\
\text { concrete) + Steel frame } \\
\text { structure (Modular units) }\end{array}$ & $\begin{array}{c}\text { Hybrid construction } \\
\text { - Concrete Core } \\
\text { (Reinforced concrete) }+ \\
\text { Steel frame structure } \\
\text { (Modular units) }\end{array}$ \\
\hline & $\begin{array}{l}\text { 1F: Concrete structure } \\
\text { 2F-4F: Modular units }\end{array}$ & $\begin{array}{l}\text { 1F: Steel Structure pilots } \\
\text { 2F-5F: Modular units }\end{array}$ & $\begin{array}{l}\text { B1F-1F and Core: } \\
\text { Concrete structure } \\
\text { 2F-5F/2F-4F: } \\
\text { Modular units }\end{array}$ \\
\hline Number of stories & 4 stories & 5 stories & $\begin{array}{c}\text { Two buildings } \\
\text { (4 stories and } 6 \text { stories) }\end{array}$ \\
\hline $\begin{array}{l}\text { Total modular } \\
\text { units, quantity }\end{array}$ & $\begin{array}{c}46 \text { units } \\
\text { (42 households) }\end{array}$ & $\begin{array}{c}18 \text { units } \\
\text { (12 households) }\end{array}$ & $\begin{array}{c}32 \text { units } \\
\text { (30 households) }\end{array}$ \\
\hline
\end{tabular}

Project N, a dormitory for undergraduate students, required a short overall construction period as it had to be completed before the beginning of class. Project $\mathrm{S}$ is located between mid-rise buildings and near an extremely narrow road. Therefore, it was necessary to shorten the duration of the on-site construction work as much as possible so as to reduce inconveniences to the residents, including noise and traffic problems, during the construction period. Project G, a Housing Environment Research Program Research and Development (R\&D) project funded by the Korean Ministry of Land, Infrastructure, and Transport, is a newly completed modular building for young people. Unlike Projects N and S, this project is the first hybrid (combined concrete core and modular unit structures), mid-rise modular building in Korea. The goals of Project $\mathrm{G}$ include the realization of a mid-rise modular building based on research results and the production of construction data for evaluating the economic feasibility and ease of construction

\subsection{Public Dormitory Construction Project}

This project constitutes the first public rental house delivered using modular construction (Figure 5). One of the reasons for using modular construction was overall construction had to be completed by the end of the university winter vacation. The entire project duration (including the contract period, project approval period, and state inspections for building use) was too short to 
accommodate conventional construction methods. In addition, the project was expected to involve about 40 non-working days during winter, due to local contract construction standards. As a result, the total planned construction duration exceeded the target construction completion time. Thus, modular construction was selected in order to both shorten the construction duration and enable the use of the building immediately after the completion of construction work. Also, modular construction was ideal for application in this project because the dormitory required the repetition of the same residential plan throughout the building. This enabled improvements in productivity and detailed quality checks on the modular construction factory floor.

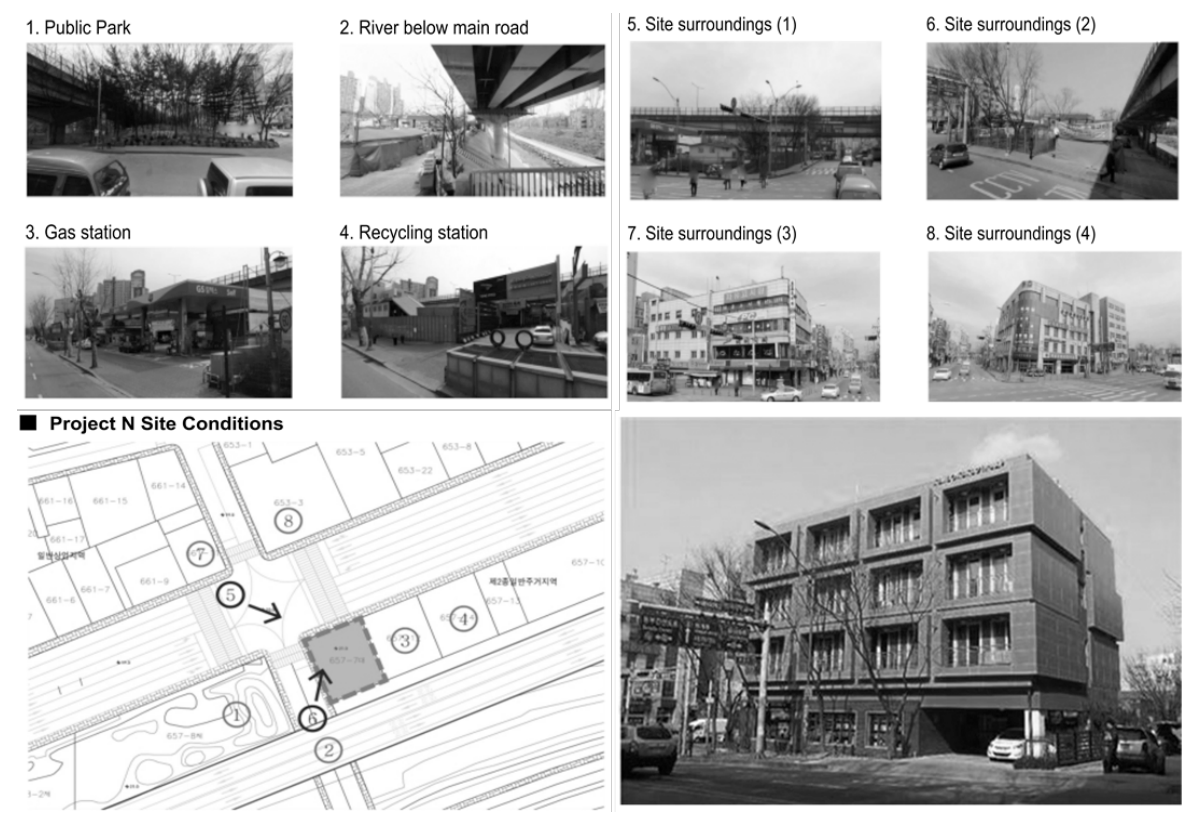

Figure 5. Project N site conditions and current state.

\subsection{Low-rise Public Rental Housing Construction Project}

In general, during the project planning phase, the total construction duration and the administrative documentation period are added to determine the move-in date, incorporating some extra time. Following this procedure, resident recruitment notices are issued approximately 3 to 4 months in advance of the move-in date, thereby minimizing the gap between the completion of construction and the move-in date. In this project, however, tenant recruitment notices were offered after the completion of construction, primarily because the building leaseholder wanted to use the building specifically for theatre; the actors needed a theatre practice space, as well as residential space. In other words, this project involved community-based rental housing where the residents can live together while practicing their performances. Therefore, residents needed to confirm their interest in establishing a residents' association after evaluating the completed building. Thus, unlike the general public housing project, the construction duration directly determined the rental income of the owner, and the quality of the building determined the lease rate. This project, however, was located on a slope in the centre of a densely populated area, and the road directly facing the site was only $6 \mathrm{~m}$ wide. These conditions greatly limited the use of heavy construction equipment, so it was difficult to ensure the planned construction duration using current construction methods. To ensure the planned construction duration and minimize local resident complaints, modular construction was used instead of conventional construction methods (Figure 6). 


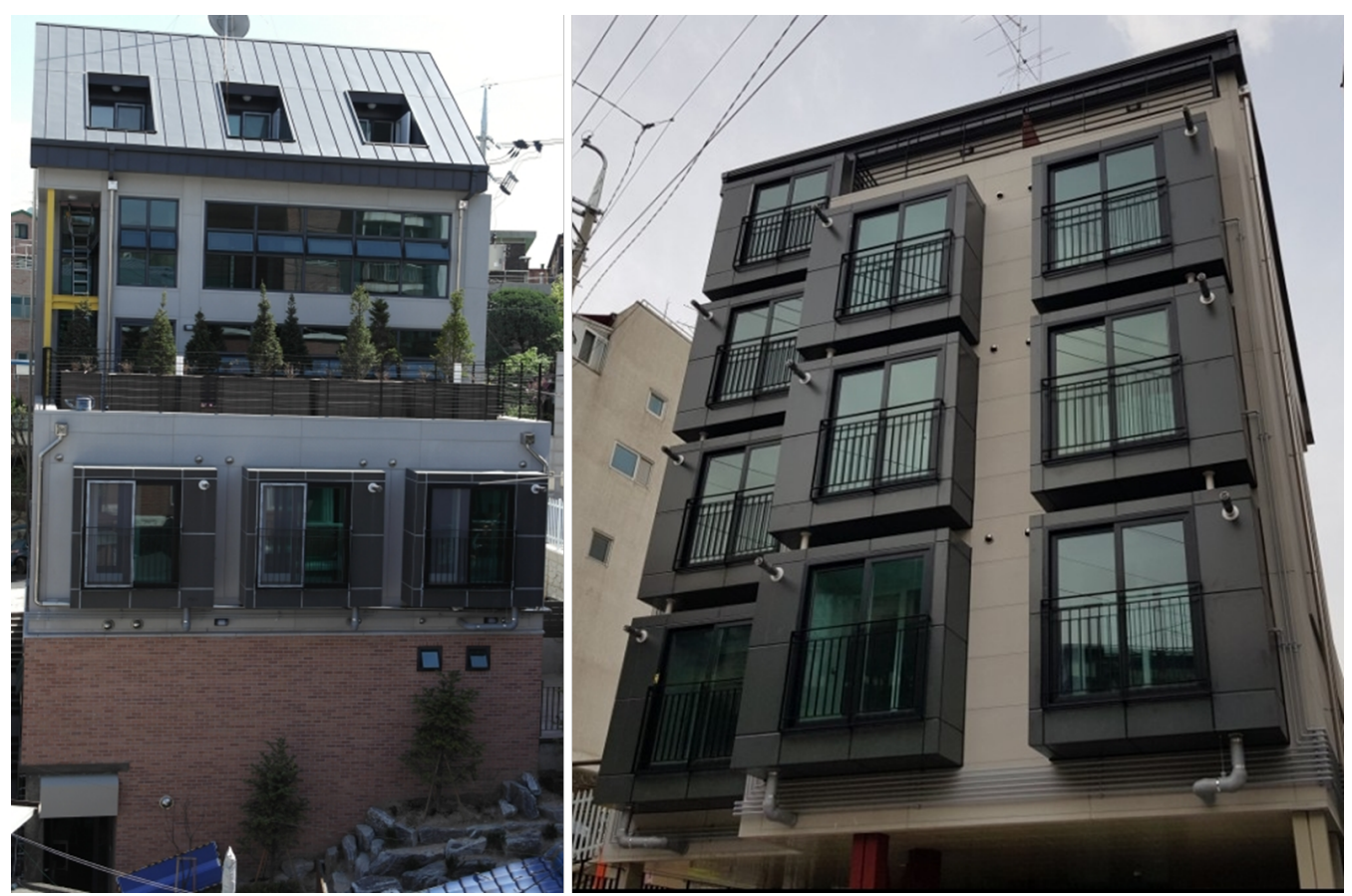

Figure 6. Project $S$ current state.

\subsection{Mid-rise Public Rental Housing Construction Project}

This project was completed under the Housing Environment Research Program funded by the Korean Ministry of Land, Infrastructure, and Transportation. This project aimed to test the technology used in the construction of the first five-story modular building in Korea and to implement modular construction research results in the construction of public rental housing. The construction process consisted of manufacturing modular units at a factory during the construction of public underground parking lots and two concrete cores $(23 \mathrm{~m}$ and $16 \mathrm{~m})$, then installing the modular units after the conclusions of the on-site construction work (Figure 7).
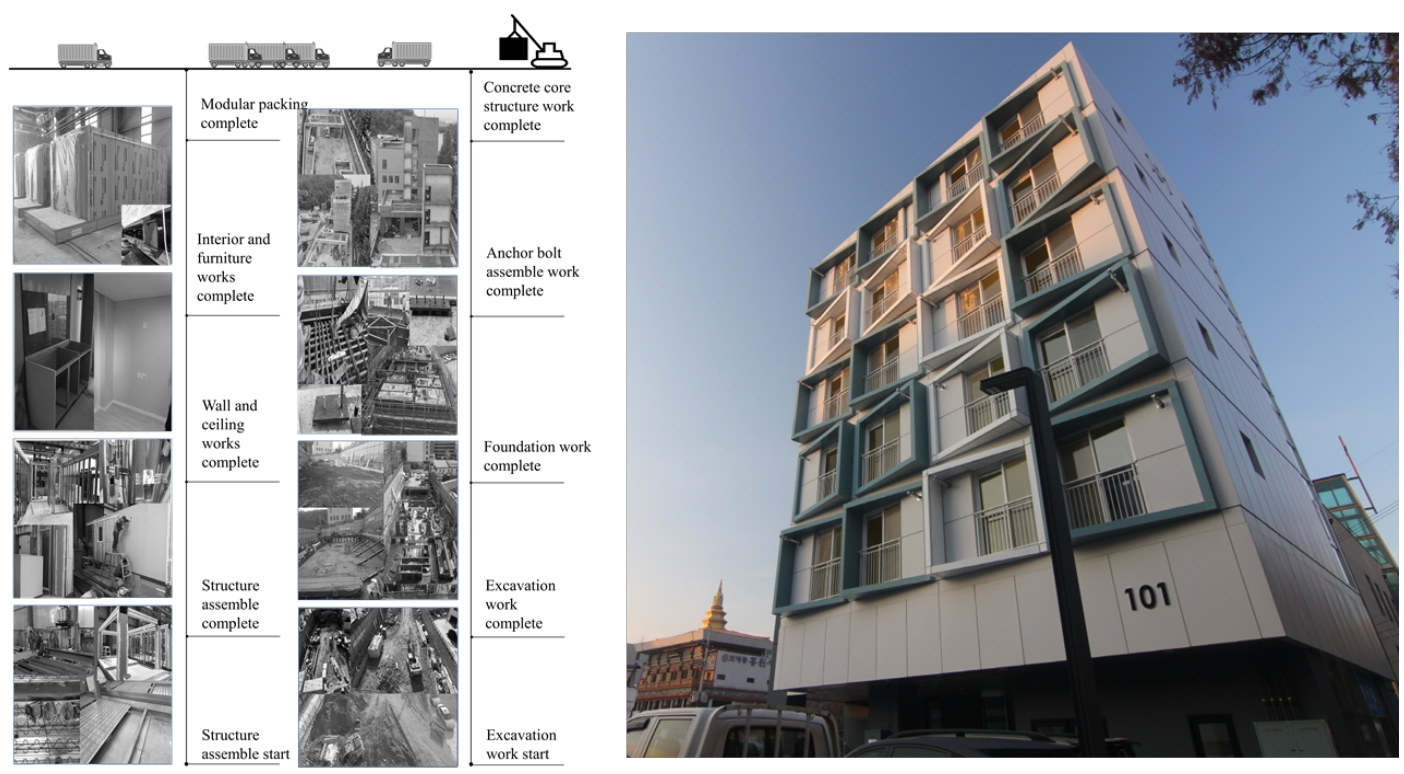

Figure 7. Overall construction process in Project G. 
One of the major research results implemented in this project was fire resistant technology developed for the drywall system to improve workability. In Korea, there are three structural fire resistance regulation levels: (1) One hour resistance in structures with fewer than four floors or less than $20 \mathrm{~m}$ in height; (2) two hours resistance in structures with more than five floors and fewer than 12 floors, or more than $20 \mathrm{~m}$ and less than $50 \mathrm{~m}$ in height; (3) three hours resistance in structures with more than 13 floors or over $51 \mathrm{~m}$ in height. According to these categories, both Project $\mathrm{N}$ and Project $S$ must meet one hour fire resistance regulations, and Project $G$ requires a two hours fire resistant structure. Before the construction of Project G, all modular building projects built in Korea had less than four floors because of the lack of dry fire-resistant technology and materials feasible from both construction and economic standpoints. Regarding fire resistance, the most important aspects of this project were the development and application of two hour dry fire resistance technology for modular buildings; such modular buildings technology has already been applied in many other countries. This research, however, aims to improve domestic technology and implement this technology in modular buildings with more than five floors.

Unlike Projects N and S, Project G was designed as a hybrid structure to resist horizontal and vertical loads; the elevator and stairs were constructed using reinforced concrete, while the residential spaces were manufactured as modular units. In this case, it is important to focus on time management at two different sites, including modular unit manufacturing time and concrete core construction time. The modular production in this project was performed in a leased general manufacturing factory rather than the modular production factory in order to perform research and development tests and conduct a feasibility assessment under a changing factory production environment.

\section{Results}

To analyse the effect of using modular construction, this paper simulated the construction of the three modular projects using conventional construction methods. Construction costs and duration were calculated using conventional PCRH standard construction calculation factors from the Seoul Housing and Communities Corporation (Figure 8).

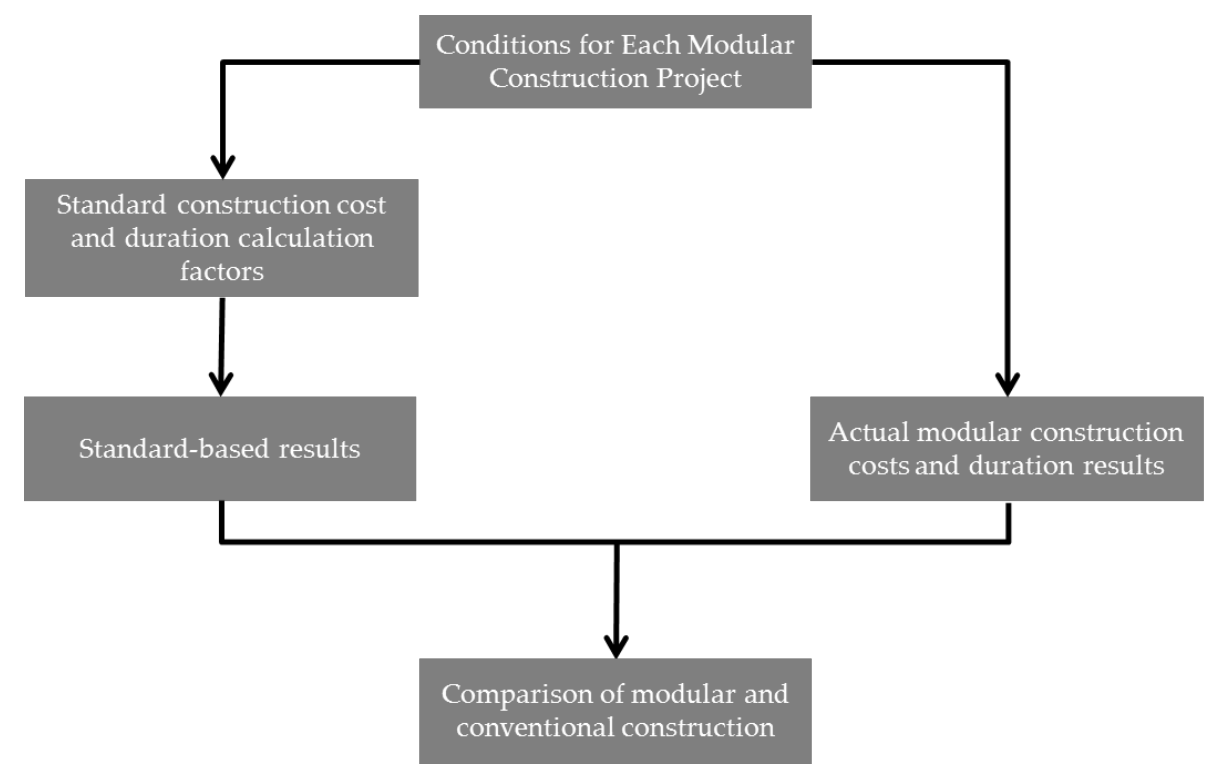

Figure 8. Overview of the analysis process.

The standard PCRH construction cost and duration calculation factors were constructed from historical PCRH construction project data from the Seoul Housing and Communities Corporation. These factors have been revised using construction market data. In this paper, the latest factors were applied to all three modular construction projects, which had different completion dates, in order to 
compare them on a common basis. When applying the conventional construction methods to the actual small-scale PCRH project, the calculation reflected the minimum value after adjustment for project conditions. Unlike the construction cost factors, the construction duration factors are limited because of the lack of legal implements and the differences in standards between the various institutions building PCRH units. The classification factors for the duration calculations are shown in Tables 6 and 7.

Table 6. Modified construction duration calculation standard factors for PCRH (2016).

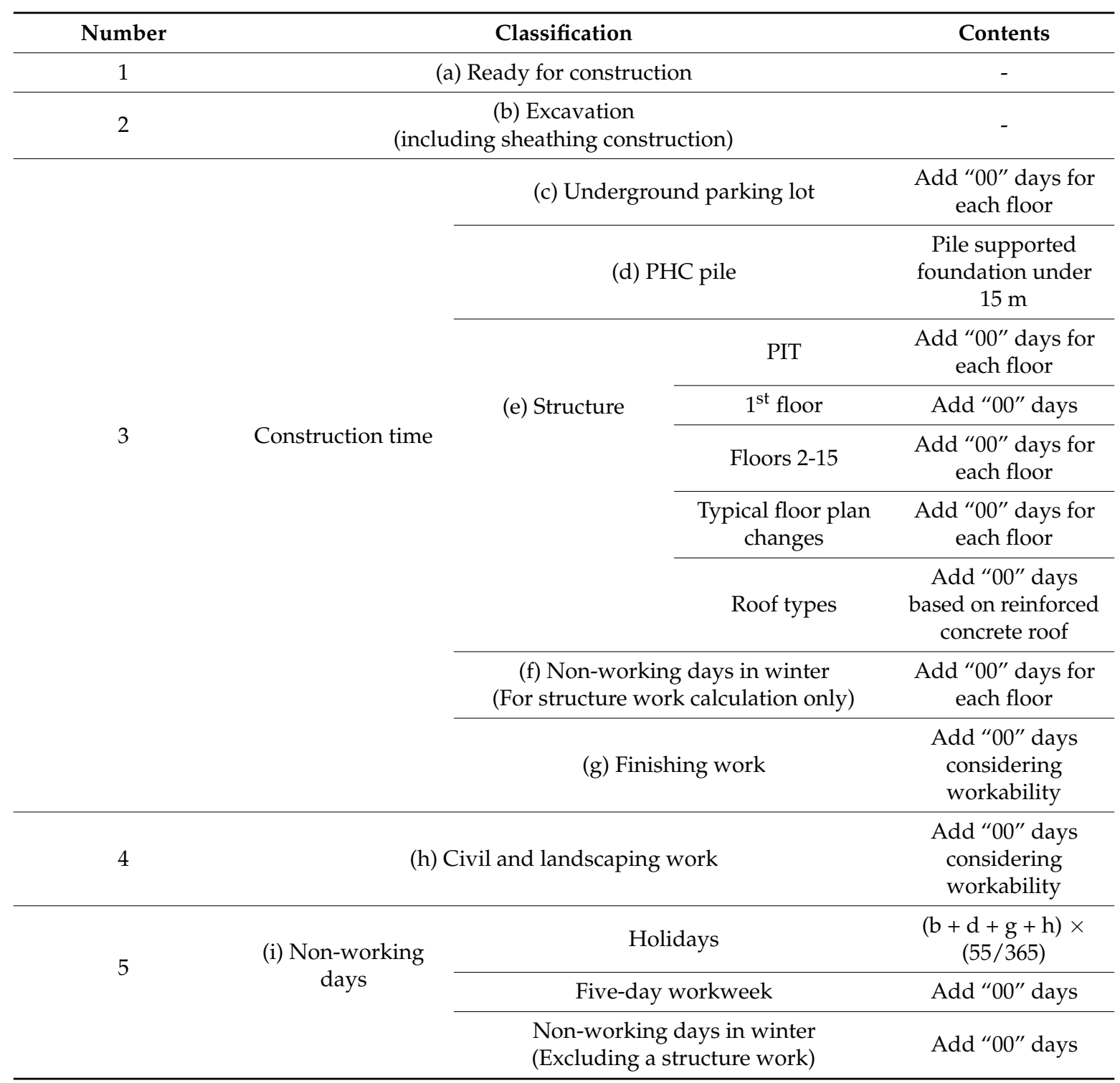

${ }^{*}$ Note: During the winter period (every 20 December to 17 January), additional non-working days are added relating the structure correction work, finishing work, and landscape work. Furthermore, the " 00 " days will change with the specific project according to workability and the project manager's experience. 
Table 7. Modified standard construction cost calculation factors for PCRH (2016).

\begin{tabular}{|c|c|c|c|}
\hline \multicolumn{3}{|c|}{$\begin{array}{c}\text { Ground classification } \\
\text { (based on exclusive residential area) }\end{array}$} & $\begin{array}{l}\text { Construction costs (Unit: } 1,000 \mathrm{won} / \mathrm{m}^{2} \text { ) } \\
\text { (based on area of housing provision) }\end{array}$ \\
\hline \multicolumn{3}{|c|}{ Under $40 \mathrm{~m}^{2}$} & 1,429 \\
\hline \multicolumn{3}{|c|}{ Over $40 \mathrm{~m}^{2}$ and Under $50 \mathrm{~m}^{2}$} & 1,452 \\
\hline \multicolumn{3}{|c|}{ Over $50 \mathrm{~m}^{2}$ and Under $60 \mathrm{~m}^{2}$} & 1,407 \\
\hline \multicolumn{3}{|c|}{ Over $60 \mathrm{~m}^{2}$ and Under $85 \mathrm{~m}^{2}$} & 1,421 \\
\hline \multicolumn{3}{|c|}{ Over $85 \mathrm{~m}^{2}$ and Under $105 \mathrm{~m}^{2}$} & 1,471 \\
\hline \multicolumn{3}{|c|}{ Over $105 \mathrm{~m}^{2}$ and Under $125 \mathrm{~m}^{2}$} & 1,449 \\
\hline \multicolumn{3}{|c|}{$\begin{array}{l}\text { Underground classification } \\
\text { (based on exclusive residential area) }\end{array}$} & Construction costs (Unit: 1,000 won $/ \mathrm{m}^{2}$ ) \\
\hline \multirow{2}{*}{ Area criterion } & \multicolumn{2}{|c|}{ Under $85 \mathrm{~m}^{2}$} & 772 \\
\hline & \multicolumn{2}{|c|}{ Over $85 \mathrm{~m}^{2}$} & 808 \\
\hline \multicolumn{3}{|c|}{ Classification of additional construction costs: Add conditions } & $\begin{array}{l}\text { Add rate } \\
\text { (based on Ground and underground } \\
\text { construction costs) }\end{array}$ \\
\hline \multirow{5}{*}{ Structure criterion } & \multirow[t]{3}{*}{ Ground } & $\begin{array}{l}\text { Reinforced concrete } \\
\text {-rhamen structure } \\
\text { (including mushroom } \\
\text { construction) }\end{array}$ & $5 \%$ \\
\hline & & $\begin{array}{c}\text { Steel frame } \\
\text { Reinforced concrete }\end{array}$ & $10 \%$ \\
\hline & & Steel structure & $16 \%$ \\
\hline & \multirow[t]{2}{*}{ Underground } & $\begin{array}{c}\text { Steel frame } \\
\text { Reinforced concrete }\end{array}$ & $4.8 \%$ \\
\hline & & Steel structure & $10.5 \%$ \\
\hline
\end{tabular}

* Note: (1) Exclusive residential area: Sum of room areas (bed room, living room, kitchen room, and bath room); (2) Housing provision area: Sum of exclusive residential areas and public residential areas (stairs, E/V, building entrance, and corridors).

Based on these factors, overall construction costs were calculated, as shown in Figure 9. In terms of construction costs, the three modular construction projects were more expensive than the factor-based calculated cost results. These projects had to be completed under shorter construction deadlines than originally planned, due to unexpected changes in project conditions, such as requirements for handling civil affairs and delays in passing the public architecture design assessment. Thus, these projects were carried out with some urgency and new modular design conditions, both of which make it difficult for modular manufacturers to purchase materials and supply manpower at reasonable prices.

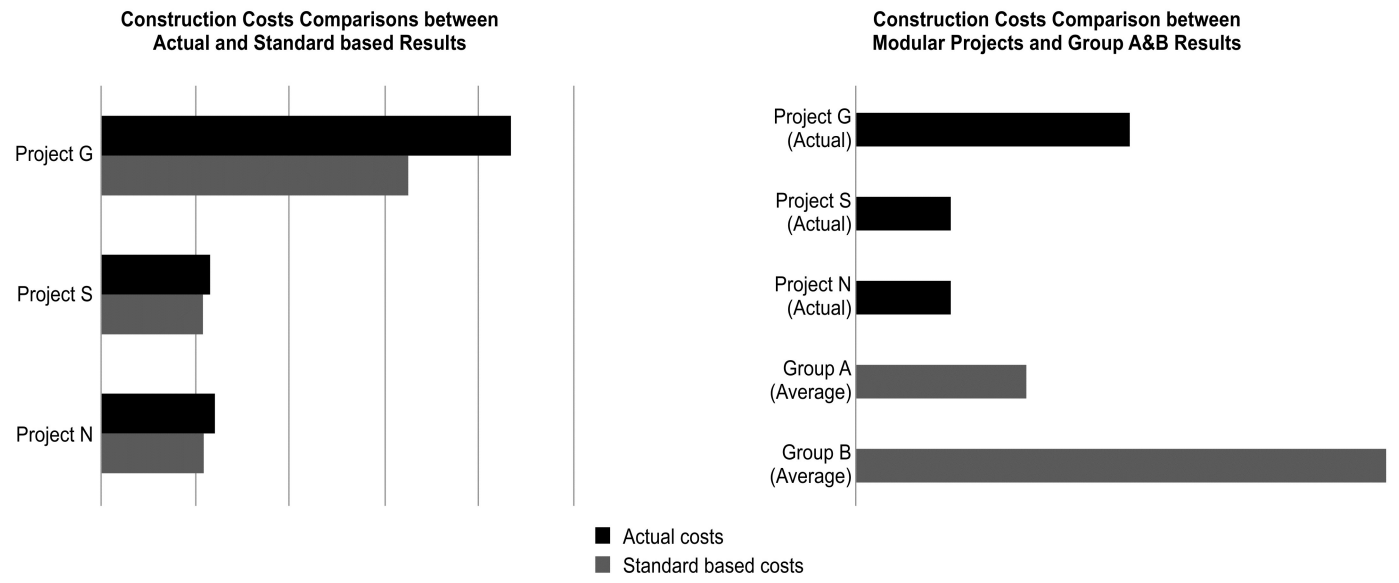

Figure 9. Actual, factor-based, and Group A and B average construction costs. 
In particular, the results show that modular Project $\mathrm{G}$ is more expensive than the standard-based cost result. In the standard cost calculation, the standard construction cost is classified based on the residential area of one house because, in most construction projects, the housing covers the entire construction area. Project G, however, has two indicators, the coverage ratio and the floor area ratio, which determine the residential area over the same land area; both indicators were lower than those calculated for Projects N and S (Figure 10).
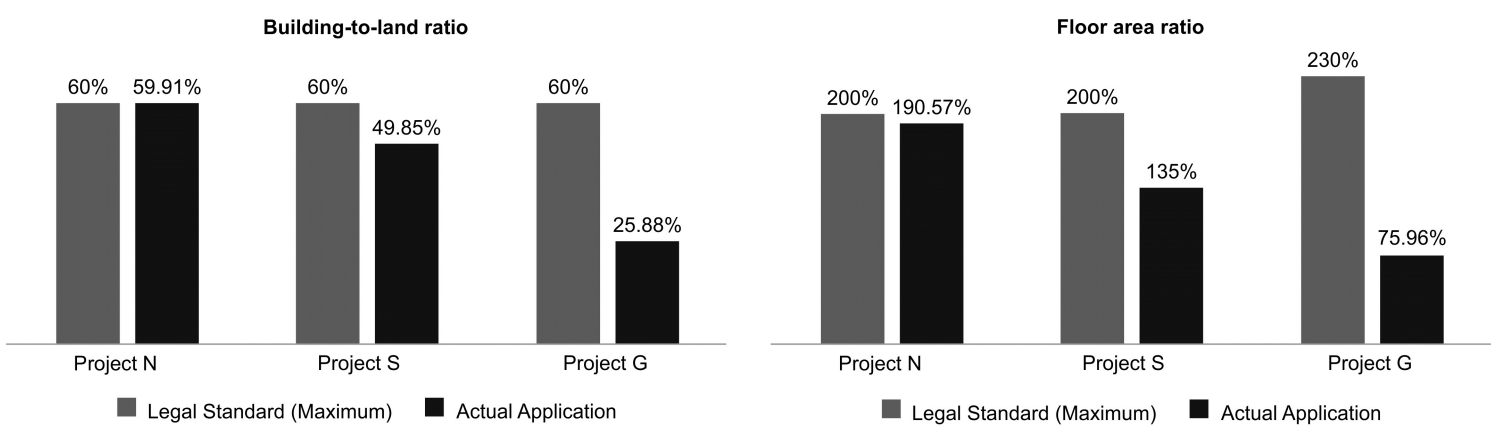

Figure 10. Comparison of building-to-land ratios and floor area ratios in modular projects.

This indicates that the total construction cost of Project $G$, calculated using the standard factors, is lower, but the actual construction cost is higher because the housing covers the entire construction area. As shown in Figure 8, Project $G$ constructed residential units at a lower legal standard level than the other two projects. Therefore, the total construction cost does not differ substantially from that of the existing construction method.

The construction durations of the three modular construction projects were much shorter than those estimated for standard construction techniques (Figure 11), partially because residential construction was completed in the factory (off-site) during the foundation work period (on-site). Considering that these modular construction projects involved an urgent ordering process, the actual building durations were shorter (more efficient) than those estimated for standard construction techniques.
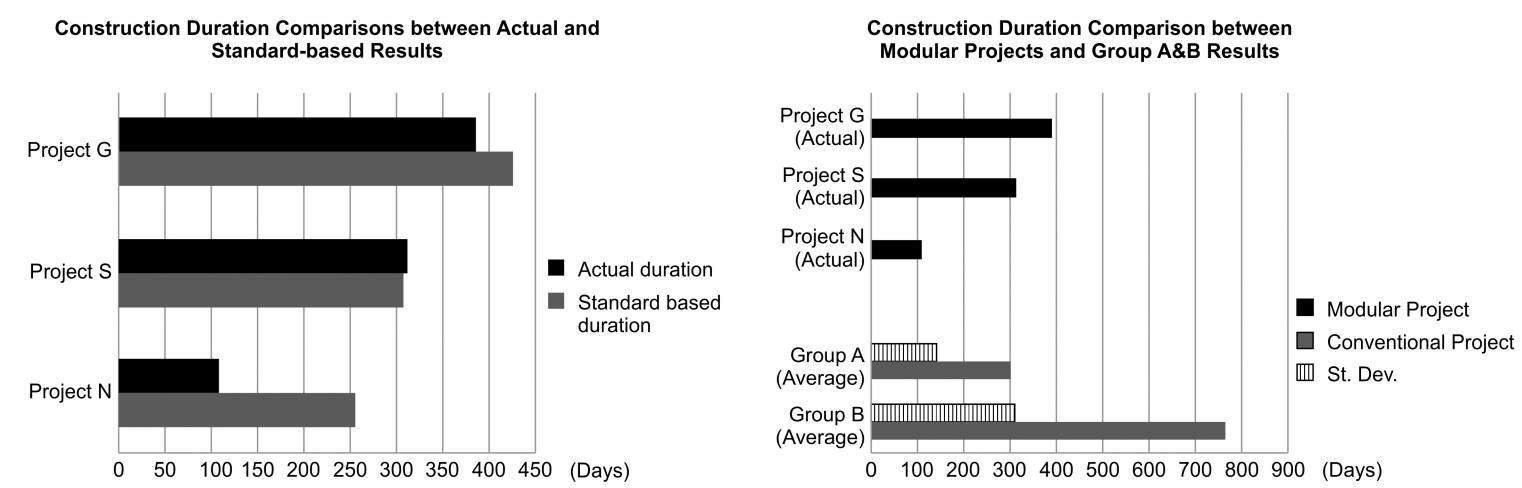

Figure 11. Construction durations of actual, standard-based, and average Group A and B results.

\section{Discussions}

The construction durations of the three modular construction projects were much shorter than those estimated for standard construction techniques (Figure 11), partially because residential construction was completed in the factory (off-site) during the foundation work period (on-site). Considering that these modular construction projects involved an urgent ordering process, the actual building durations were shorter (more efficient) than those estimated for standard construction techniques. 


\subsection{Schedules that Account for the Effect of On-site Construction Work or Resource Supply Delays on the Modular Unit On-site Installation Schedule}

The manufacturing schedule of small-scale PCRH project involving modular construction is determined by the on-site construction schedule, as the on-site construction working takes longer than the off-site construction work. Thus, the scheduling of small-scale PCRH modular construction projects should be based on site-based construction scheduling methods. Small-scale PCRH site-based (conventional) construction scheduling is focused on the resources (materials and labors) planning that constantly ensures adequate resource supply, except for specific materials, such as those supplied by the government. Small-scale PCRH development projects, in particular, are performed by mid-size construction companies. The company purchases materials and organizes workers at the beginning of the project on a nearby construction site. Therefore, it is difficult to ensure the smooth supply of materials and manpower during construction work.

In the case of Project G, for example, two large-scale construction development projects were in operation near the Project $G$ construction site. At the beginning of Project $G$, the work schedules of the two large-scale construction projects did not affect the Project $G$ schedule. Due to weather, however, concrete core work schedules increasingly overlapped in the two projects and Project G. As we know, concrete must be transported and poured two hours before use at the construction site to ensure concrete quality. As a result, the concrete material supplier, who had contracted both the two large-scale projects and Project G, first supplied concrete materials to the two large-scale projects, even though Project $\mathrm{G}$ was supposed to be supplied first. This delayed the Project $\mathrm{G}$ concrete core construction schedule by a few days, which affected the modular unit installation schedule. This problem also occurred in Projects N and S during modular unit production, although the Project G delay was caused by one piece of on-site work, while the Project $N$ and $S$ delays were accumulated from a few small on-site work delays. To avoid this problem, this paper proposes a scheduling method that focuses on the on-site installation schedule of modular construction.

The conventional construction project was used to make a schedule from the start date or end date of the project, but modular construction is more suitable to determine the whole construction schedule based on the site installation date. For example, when a project manager or a schedule manager makes an entire modular project schedule, it divides the remaining construction schedule after the modular unit on-site installation date is first determined. With this method, if the construction schedule is determined based on the site installation date, the time buffer can be set based on the site installation schedule, thereby reducing the risk for the entire construction period.

\subsection{Use Mass Production to Reduce PCRH Construction Costs}

Modular construction consists of a combination of manufacturing production processes and conventional construction work. There are various reasons for applying manufacturing production processes in construction, but chief among them is a reduction in construction cost via mass production by the manufacturing industry. Mass production systems are capable of purchasing large quantities of materials, which can not only reduce the cost, but also improves productivity and quality via worker repetition. Modular PCRH construction projects have the advantage of more rapid project initiation (than possible under conventional construction methods) when construction demand occurs. In other words, in modular construction, the necessary materials can be prepared in advance, at the beginning of the project. It will reduce the risk of increased construction costs during construction by stabilizing the supply of resources.

\subsection{Environmental Sustainaility Effect of Modular Construction Project from a Perspective of Public Developer}

Based on the results of three modular construction projects, there were two environmental benefits of modular construction from the perspective of a public developer. First, modular construction has the effect of resource saving and productivity improvement by minimizing rework. When using the conventional construction method for small-scale housing construction project, it often damages the 
already finished results because several works are in progress at the same time in small workspaces. In modular construction, on the other hand, rarely affects other works because it works at a fixed time and workspace. Therefore, modular coustricon can reduce the probability of reworking compared to conventional construction, which not only saves materials, but also improves productivity. Second, environmentally friendly technology can be applied at a lower cost than conventional construction method. Environmental sustainability construction is important to strengthen sustainable urban development. This phenomenon is increasingly being applied regardless of the type and scale of the construction project. For quantitative measurement and motivation of this, LEED certification or national green building construction certification has been used worldwide [31-33]. These certifications have several specific categories and measurement methods, so project owner or designer can choose these items to achieve reasonable certification level, taking into account the total project budget, design characteristics, and building type [34]. From a public devleoper perspective, however, the application of environmentally friendly construction technology of small-scale projects is more difficult and expensive than large-scale construction projects. One of the reasons is that items and alternative technologies are limited for achieving eco-friendly scores in a small-scale project. Therefore, it has been recognized that conventional construction method using small-scale construction project is low in ecnonomic efficiency. In modular construction, most materials and products are connceted in an easy-to-assemble and disassemly process. Thus, modular construction projects can achive a high score in the "Materials and Resoruces" category. These are not only good for high scores, but also save manitenace costs, which is an atrractive part of the public developer. In addition, modular construction has the advantages of being able to apply customized technology at low cost because it enables the selective application of specific environmentally friendly technology for each tenant at the factory production stage. This is useful in reducing unncessary cost wastage and enabling the resident to apply the desired green tehcnology.

\section{Conclusions}

Public rental housing is important both for people who need guaranteed low-cost housing welfare and those who need residential stability until it becomes economically possible to buy a house. For sustainable urban development, these houses should be constructed to minimize environmetal degradation at resonable construction costs. Moreover, it has to be constructed in order for public rental housing to satisfy both the provider and the consumer simultaneously, such housing must deliver both reasonable construction costs and rapid supply.

The results in thisp aper show that modular construction methods can be feasibly applied in PCRH projects in South Korea. Despite construction costs and durations somewhat higher than those announced in other countries, modular construction methods remain a feasible alternative for small-scale PCRH development projects without design standarization implementation. To further assess the applicability of modular construction in PCRH, the post-occupancy evaluation (POE) results of three modular construction projects will be analysed in future work.

Author Contributions: Conceptualization, J.L. and J.K.; methodology, J.L.; formal analysis, H.L. and Y.L.; investigation, J.L. and H.K.; resources, J.K and H.K.; data curation, J.L.; writing-original draft preparation, J.L.; writing—review and editing, J.L and H.K.; visualization, J.L.; funding acquisition, J.L..

Funding: This research was funded by the Ministry of Land, Infrastructure and Transportation of Korean Government, Housing Environment Research Program (Grant number 17AUDP-C068793-05-000000).

Acknowledgments: The authors would also like thanks to Urban Research Institute of Seoul Housing Communities and Corporation and Ministry of Land, Infrastructure and Transportation of Korean Government, Housing Environment Research Program for supporting the research process.

Conflicts of Interest: The authors declare no conflict of interest. 


\section{References}

1. Butlin, J. Our common future. By World commission on environment and development. J. Int. Dev. 1989, 1, 284-287. [CrossRef]

2. Bruntland, G. Our Common Future: The World Commission on Environment and Development; Oxford University Press: Oxford, UK, 1987.

3. Wills, B. Green Intentions; Productivity Press: New York, NY, USA, 2009.

4. U.S. Environmental Protection Agency (EPA). Lean Manufacturing and Environment. Available online: https: / /www.epa.gov/lean/lean-manufacturing-and-environment (accessed on 11 February 2019).

5. Whole Building Design Guide Sustainable (WBDG). Available online: http://www.wbdg.org/designobjectives / sustainable (accessed on 11 February 2019).

6. Nahmens, I.; Ikuma, L.H. Effects of lean construction on sustainability of modular homebuilding. J. Archit. Eng. 2012, 18, 155-163. [CrossRef]

7. Lee, J.; Park, M.; Lee, H.S.; Kim, T.; Kim, S.; Hyun, H. Workflow dependency approach for modular building construction manufacturing process using dependency structure matrix (DSM). KSCE J. Civ. Eng. 2017, 21, 1525-1535. [CrossRef]

8. Lawson, R.M.; Ogden, R.G.; Bergin, R. Application of modular construction in high-rise buildings. J. Archit. Eng. 2011, 18, 148-154. [CrossRef]

9. Molavi, J.; Barral, D.L. A construction procurement method to achieve sustainability in modular construction. Procedia Eng. 2016, 145, 1362-1369. [CrossRef]

10. Pan, W.; Sidwell, R. Demystifying the cost barriers to offsite construction in the UK. Constr. Manag. Econ. 2011, 29, 1081-1099. [CrossRef]

11. Boafo, F.E.; Kim, J.-H.; Kim, J.-T. Performance of modular prefabricated architecture: Case study-based review and future pathways. Sustainability 2016, 8, 558. [CrossRef]

12. Shen, K.; Cheng, C.; Li, X.; Zhang, Z. Environmental Cost-Benefit Analysis of Prefabricated Public Housing in Beijing. Sustainability 2019, 11, 207. [CrossRef]

13. O'Brien, M.; Wakefield, R.; Belivean, Y. Industrializing the Residential Construction Site; Department of Housing and Urban Development, Office of Policy Development and Researce: Washington, DC, USA, 2000.

14. McGraw Hill Construction. Prefabrication and modularization: Increasing productivity in the construction industry; Smart Market Report; McGraw Hill Construction: Hightstown, NJ, USA, 2011.

15. Lawson, R.M.; Ogden, R.G. Sustainability and process benefits of modular construction. In Proceedings of the 18th CIB World Building Congress, Salford, UK, 10-13 May 2010.

16. Kawecki, L.R. Environmental Performance of Modular Fabrication: Calculating the Carbon Footprint of Energy Used in the Construction of a Modular Home. Ph.D. Thesis, Arizona State University, Phoenix, AZ, USA, 2010.

17. Kamali, M.; Hewage, K. Development of performance criteria for sustainability evaluation of modular versus conventional construction methods. J. Clean. Prod. 2017, 142, 3592-3606. [CrossRef]

18. Xie, Z.; Hall, J.; McCarthy, I.P.; Skitmore, M.; Shen, L. Standardization efforts: The relationship between knowledge dimensions, search processes and innovation outcomes. Technovation 2016, 48, 69-78. [CrossRef]

19. Cheng, I.; Yeung, C.K.Y.; Fung, C.K.Y.; Lai, W.K.W. Affordable social housing: Modular flat design for mass customization in public rental housing in Hong Kong. In Proceedings of the SB11 Helsinki World Sustainable Building Conference, Helsinki, Finland, 18-21 October 2011.

20. Aapaoja, A.; Haapasalo, H. The Challenges of Standardization of Products and Processes in Construction. In Proceedings of the 22nd Annual Conference of the International Group for Lean, Olso, Norway, 25-27 June 2014; pp. 983-993.

21. Gibb, A.G.F. Standardization and pre-assembly-distinguishing myth from reality using case study research. Constr. Manag. Econ. 2001, 19, 307-315. [CrossRef]

22. Jiang, L.; Li, Z.; Li, L.; Gao, Y. Constraints on the promotion of prefabricated construction in China. Sustainability 2018, 10, 2516. [CrossRef]

23. Musa, M.F.; Mohammad, M.F.; Mahbub, R.; Yusof, M.R. Enhancing the quality of life by adopting sustainable modular industrialised building system (IBS) in the Malaysian construction industry. Procedia-Soc. Behav. Sci. 2014, 153, 79-89. [CrossRef] 
24. Musa, M.F.; Mohammad, M.F.; Mahbub, R.; Yusof, M.R. Adopting Modular Construction in the Malaysian Construction Industry. Asian J. Environ.-Behav. Stud. 2018, 3, 1-9. [CrossRef]

25. Doran, D.; Giannakis, M. An examination of a modular supply chain: A construction sector perspective. Supply Chain Manag. 2011, 16, 260-270. [CrossRef]

26. Pan, W.; Gibb, A.G.; Dainty, A.R. Perspectives of UK housebuilders on the use of offsite modern methods of construction. Constr. Manag. Econ. 2007, 25, 183-194. [CrossRef]

27. Statistics Korea. Available online: www.kostat.go.kr (accessed on 23 October 2018).

28. Nahmens, I.; Mullens, M.A. Lean home building: Lessons learned from a precast concrete panlizer. J. Archit. Eng. 2011, 17, 155-161. [CrossRef]

29. Arashpour, M.; Ab2basi, B.; Arashpour, M.; Hosseini, M.R.; Yang, R. Integrated management of on-site, coordination and off-site uncertainty: Theorizing risk analysis within a hybrid project setting. Int. J. Proj. Manag. 2017, 35, 647-655. [CrossRef]

30. Björnfot, A.; Stehn, L. Industrialization of construction: A lean modular approach. In Proceedings of the Annual Conference of the International Group for Lean Construction, Elsinore, Denmark, 3-5 August 2004.

31. Pushkar, S. The Effect of Regional Priority Points on the Performance of LEED 2009 Certified Buildings in Turkey, Spain, and Italy. Sustainability 2018, 10, 3364. [CrossRef]

32. Illankoon, I.M.C.S.; Tam, V.W.Y.; Le, K.N. Environmental, economic, and social parameters in international green building rating tools. Prof. Issues Eng. Educ. Pract. 2017, 143, 05016010. [CrossRef]

33. Shen, W.; Tang, W.; Siripanan, A.; Lei, Z.; Duffield, C.; Hui, F. Understanding the Green Technical Capabilities and Barriers to Green Buildings in Developing Countries: A Case Study of Thailand. Sustainability 2018, 10, 3585. [CrossRef]

34. Wu, P.; Song, Y.; Hu, X.; Wang, X. A Preliminary Investigation of the Transition from Green Building to GreenCommunity: Insights from LEED ND. Sustainability 2018, 10, 1802. [CrossRef]

(C) 2019 by the authors. Licensee MDPI, Basel, Switzerland. This article is an open access article distributed under the terms and conditions of the Creative Commons Attribution (CC BY) license (http://creativecommons.org/licenses/by/4.0/). 